\title{
A Perspective From Indonesian Tourists: The Influence Of Destination Image On Revisit Intention
}

Bob Foster, Universitas Informatika Dan Bisnis Indonesia, Indonesia Iwan Sidharta, Sekolah Tinggi Ilmu Ekonomi Pasundan, Indonesia

\begin{abstract}
The tourism sector becomes a central issue in the growth of a state. Researchers have proven the critical role of domestic and foreign tourists visits in raising the state revenue. Some studies have shown the role of destination image in increasing the tourist to revisit. However, some research models have various ways of explaining the effect of destination image on the tourists' loyalty to revisit. Therefore, this study wants to determine the effect of destination image towards tourists revisit intentions in several cities in Indonesia. This research uses the quantitative approach to answer the purpose of research. The results reveal that destination image has an impact on tourists revisit intentions. To improve the revisit intention, it is necessary for the regulators to make improvements associated with several variables that form the destination image. Besides, the tourists and travels providers must accommodate a memorable experience so that the tourists are satisfied during their visits.
\end{abstract}

Keywords: Tourist; Travel; Destination Image; Revisit Intention

\section{INTRODUCTION}

( $\mathrm{n}$ general, tourism industry can be defined as an industry that connected to all tourism activities and facilities to accomplish the whole activities. Later, it adds the goods and services value needed in tourism activities. Tourism has a vital role in economic development. Moreover, it is an indicator of a country's competitive power against to the other countries, both regionally and globally.

The government has predicted and targeted tourism sector as the new core-economy for the improvement of Indonesian economy. It has a significant contribution of target to Gross Domestic Product (GDP) through increasing the foreign exchange. This sector not only increases the foreign exchange, but also opens various jobs opportunities and forms the economic equality in each region.

Indonesia has abundant tourism resources. The tourism resources consists of the charm of natural wealth, relics of ancient civilization, cultural diversity \& customs and the other potentials that can be developed into a brand image and characteristic of Indonesian tourism. In this case, it is called Destination Image. The creation of terrific Destination Image affects the customer loyalty.

Customer relationships and loyalty were built on customer loyalty in the context of tourism. The tourist loyalty has been studied since the 1990s (Dimanche \& Havitz, 1995). The levels of loyalty from a product perspective can be seen from their behavioral intentions to revisit their goals and recommend the experience to the others.

Previous research has discussed tourists loyalty related to satisfaction, service quality, and perceived value (Chen \& Chen, 2010; Huang \& Hsu, 2009; Mechinda, Serirat \& Guild, 2009; Ramkissoon, Uysal, \& Brown, 2011). The experience felt by tourists plays a vital role in deciding the purpose of visiting (Gallarza, Saura \&García, 2002). As studied by Horng, Liu, Chou \& Tsai, 2012; Hung \& Petrick, 2012; the tourist loyalty is determined by the intention to recommend. 
Theoretically, the destination image can be viewed from three approaches. The cognitive component is the belief and knowledge that tourists have from the tourist destination attribute. Emotional responses to various additional attractions represent affective components. While the conative aspect is the tourists' consumptive behavior in tourist attractions (Chen \& Phou, 2013).

Consumer confidence about the received value leads to their overall attitudes toward the product or service, such as the intention to buy back (Yoon \& Uysal, 2005), as a behavior, including recommendation and the relationship between relative attitudes and repeat patronage.

The literature study of tourist loyalty can be viewed from behavior aspects, attitude and composite loyalty (Zhang, Fu, Cai \& Lu, 2014). Behavioral loyalty focuses on behavioral outcomes such as repeating visits, tourists' emotional experience such as the intention to revisit the destination or recommend it to others and integration of both previously referred attitudes and behaviors (Zhang et al. 2014).

The results show destination image influences the tourists' loyalty, as indicated by the intention to return, tend to stay longer and give the positive words of mouth (Chi \& $\mathrm{Qu}, 2008)$. Some results show the destination image that dominantly influences the tourists' loyalty is the aspect of composite loyalty which is the revisit intention. There are various approaches made by the previous researchers. This study intends to determine the effect of destination image on the revisit intention which is the aspect of composite loyalty.

In this research, the brand image of Indonesian tourism is represented by destination image variable. Then, the level of tourists' loyalty in visiting Indonesia's tourist destinations is represented by revisit intention. With these considerations, this study aims to determine the effect of the destination image on the revisit intention.

\section{METHODS}

This research uses predictive modeling approach with the purpose of exploring the variables that create the destination image. The referred variables are lodging facility, quality of food and relaxation experiences through variance-based SEM approach in which the hypothesis testing is done with the non-parametric approach by using Partial Least Square (PLS).

This study uses a representative sampling method in representing the population. To collect the data, this research utilizes the probability sampling technique with simple sampling technique. Thoroughly, 600 questionnaires were distributed directly in some major tourist destinations in Indonesia with predetermined proportionality. The number of representative and cooperative respondents are 463 people. However, only 167 questionnaires are valid.

The measurement of the destination image is represented by lodging facility with five items of research instrument; quality of food with four items of research instruments and relaxation experiences with six items of research instruments. A revisit intention measurements are five items of research instrument adopts the TPB approach (Ajzen, 1988). Therefore, the total instrument used in the study are 20 instruments with 5 Likert scale in determining the perception of measurement.

The data from questionnaires were analyzed with the non-parametric approach of Partial Least Square which is according to Outer Loading Indicator $>0.5$. The reliability refers to Average Variance Extracted $>0.5$, Cronbach Alpha $>0.7$ and Composite Reliability $>0.7$ (Kock, 2012). Table 1 and Table 2 show the result of validity and reliability. 
Table 1. Research Variables Outer Loading Indicator Validity

\begin{tabular}{|c|c|c|c|c|}
\hline Indicator & Lodging & Quality & Relax & Intention \\
\hline Lo_1 & 0.830 & & & \\
\hline Lo_2 & 0.850 & & & \\
\hline Lo_3 & 0.877 & & & \\
\hline Lo_4 & 0.882 & & & \\
\hline Lo_5 & 0.779 & & & \\
\hline $\mathrm{Qu}_{-} 1$ & & 0.815 & & \\
\hline $\mathrm{Qu} 2$ & & 0.866 & & \\
\hline $\mathrm{Qu} 3$ & & 0.868 & & \\
\hline $\mathrm{Qu} \_4$ & & 0.812 & & \\
\hline Re_1 & & & 0.675 & \\
\hline $\mathrm{Re} \_2$ & & & 0.709 & \\
\hline $\mathrm{Re}^{-} 3$ & & & 0.763 & \\
\hline Re_4 & & & 0.704 & \\
\hline Re_5 & & & 0.780 & \\
\hline $\operatorname{Re} \_6$ & & & 0.786 & \\
\hline In_-1 & & & & 0.775 \\
\hline In_-2 & & & & 0.811 \\
\hline In_3 & & & & 0.739 \\
\hline In_4 & & & & 0.781 \\
\hline In 5 & & & & 0.695 \\
\hline
\end{tabular}

According to the assessment of validity indicators. The research variables are eligible to be used in the research. Besides, the output validity test by using the value of outer loading indicator shows all instruments fulfill the criteria of validity assessment of 0.5 . Therefore, they are qualified to be used in the research.

Table 2. The result of Average Variance Extracted (AVE), Cronbach's Alpha and Composite Reliability

\begin{tabular}{l|c|c|c}
\hline \multicolumn{1}{c}{ Variables } & AVE & Cronbach's Alpha & Composite Reliability \\
\hline Lodging Facility & 0.719 & 0.928 & 0.928 \\
\hline Quality of Food & 0.706 & 0.861 & 0.908 \\
\hline Relaxation Experience & 0.544 & 0.831 & 0.877 \\
\hline Destination Image & 0.624 & 0.818 & 0.873 \\
\hline Revisit Intention & 0.579 & 0.779 & 0.827 \\
\hline
\end{tabular}

In general, the results of reliability test indicate that all variables in the research are reliable. It is based on reliability testing criteria by using AVE, Cronbach's Alpha, and Composite Reliability.

Following the validity and reliability test, this research model can be done to know the magnitude of destination image's influence and significance level on revisit intention and the level of tourists' loyalty in visiting the tourist destinations.

\section{DATA ANALYSIS}

The results point out there is a significant effect of destination image on the revisit intension with the value of 0.463 and P-value 0.001 as described in table 3 . Besides, figure 1 describes the research model.

Table 3. Path Coefficients Values

\begin{tabular}{c|ccc}
\hline Variables & Path Coeficient & P-Value & Decision \\
\hline Destination Image $\rightarrow$ Revisit Intention & 0.463 & 0.001 & Accept \\
\hline
\end{tabular}

Figure 1 describes the development of research model based on predicted variables that form the destination image and affect the revisit intention: 
Figure 1. Structural Model of Destination Image
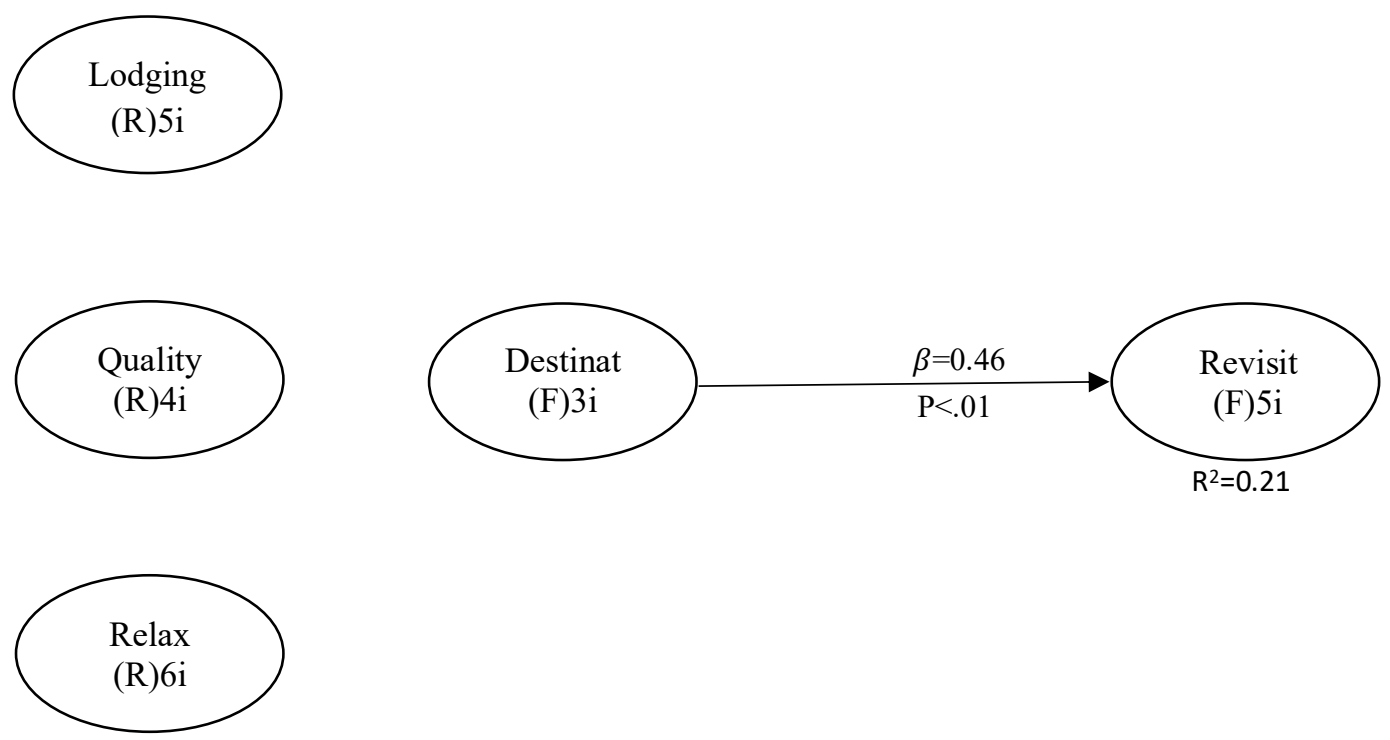

Figure 1 shows that the modeling structure of Destination Image's forming variables consists of Lodging Facility, Quality of Food and Relaxation Experiences. Furthermore, the model also describes how big the destination image influences the revisit intention.

The fit model is used to test the research model, where Average Path Coefficients (APC) shows the calculation value of 0.463 and the P-value 0.001 . The Tenenhaus Goodness of Fit (GoF) value is 0.369 , and the entire research model is classified as very good (large) because of $>0.36$.

\section{DISCUSSION}

The predictive modeling in this study was conducted based on previous research that is relevant to be applied in modeling the components of destination image such as lodging facility, quality of food and relaxation experiences. The results show that the research model is within the high criteria.

Based on the results of the calculation and analysis, it is found that almost all the research instruments or indicators on the variables used in the research proved valid, there is only one indicator in the quality of food variable that is not valid to be used in the research. Therefore, the variable only uses three research indicators. Later, there is the recalculation of the validity. Per the reliability test, all variables in this study are reliable.

In data analysis by using path analysis, it can be seen that the effect of destination image toward revisit intention has path coefficient 0.463 and P-value 0.001 . The p-value is less than $5 \%$ or 0.05 . Therefore, it can be said the destination image variable significantly influence the revisit intention.

The results of the study can be compared with the previous researches which prove that the destination image positively and significantly impacts the revisit intention. Some researchers conducted the previous researches as Chew \& Jahari (2014); Hallmann, Zehrer \& Müller (2015); Stylos, Vassiliadis, Bellou \& Andronikidis (2016); Prayag, Hosany, Muskat, Del Chiappa (2017) conducted the other studies.

In principle, Destination Image is a perception or description of the image of a tourist destination for tourists who have visited it. Automatically, the tourists have the exceptional destination image perception when they get the high level of satisfaction in tourist destinations. The tourists' high level of destination image perception will cultivate a desire to revisit as well. Therefore, destination image has a significant influence on the revisit intention in accordance with the research results. 


\section{CONCLUSION, RECOMMENDATION, AND LIMITATION}

The speedy development of the tourism industry in recent years demands the development of a holistic and sustainable tourism strategy to attract the domestic and foreign tourists to visit a tourist destination. With tourism is set as the core-economy of Indonesia in the future, the government as the regulator is required to be able to recognize what factors that significantly influence the tourists' satisfaction. Thus, the factors lead to tourists' loyalty in revisiting Indonesia's tourists' destinations. It is as the basis for determining the most optimal tourism development strategy.

The results of this study conclude that tourists' positive level of perception after visiting the tourist destinations in Indonesia will affect the tourists' intention to revisit the place. To increase the number of tourist in the next period, the results of this study provide recommendations for the regulator to corrects several variables that form the destination image to get the tourists' satisfaction during their visits. The advancing tourists' satisfaction that related to tourist destinations will increase the destination image perceptions. Furthermore, it increases tourists' perception of their loyalty to a tourist destination. In this case, it is reflected in the revisit intention.

This study has limitations in data collecting method. It uses samples and probability calculations. The sample of respondents are respondents based on Indonesia's tourist destinations with culture and habits that cannot be generalized to the other tourist destinations. Besides, this study is limited to the variables used in the research model without considering the other variables that may affect the revisit intention.

\section{AUTHOR BIOGRAPHIES}

Bob Foster is an entrepreneur, the owner of Ganesha Operation Learning Center, Rector of Universitas Informatika dan Bisnis Indonesia (Unibi) Bandung and a researcher. He graduated from Universitas Padjajaran Doctoral Program. He actively writes physics textbooks. He also has published journals both nationally and internationally.

Iwan Sidhartais a business owner, a lecturer at STIE Pasundan and a researcher. His work focuses specifically on management, business and entrepreneurship.

\section{REFERENCES}

Ajzen, I. (1988). Attitudes, Personality, and Behavior. Chicago: IL: Dorsey.

Chen, C. F., \& Chen, F. S. (2010). Experience quality, perceived value, satisfaction and behavioral intentions for heritage tourists. Tourism management, 31(1), 29-35.

Chen, C. F., \& Phou, S. (2013). A closer look at destination: Image, personality, relationship and loyalty. Tourism management, 36, 269-278.

Chew, E. Y. T., \&Jahari, S. A. (2014). Destination image as a mediator between perceived risks and revisit intention: A case of post-disaster Japan. Tourism Management, 40, 382-393.

Chi, C. G. Q., \& Qu, H. (2008). Examining the structural relationships of destination image, tourist satisfaction and destination loyalty: An integrated approach. Tourism management, 29(4), 624-636.

Dimanche, F., \&Havitz, M. E. (1995). Consumer behavior and tourism: Review and extension of four study areas. Journal of Travel \& Tourism Marketing, 3(3), 37-57.

Gallarza, M. G., Saura, I. G., \&García, H. C. (2002). Destination image: Towards a conceptual framework. Annals of tourism research, 29(1), 56-78.

Hallmann, K., Zehrer, A., \& Müller, S. (2015). Perceived destination image: An image model for a winter sports destination and its effect on intention to revisit. Journal of Travel Research, 54(1), 94-106.

Horng, J. S., Liu, C. H., Chiu, H. Y., \& Tsai, C. Y. (2012). The role of international tourist perceptions of brand equity and travel intention in culinary tourism. The Service Industries Journal, 32(16), 2607-2621.

Huang, S., \& Hsu, C. H. (2009). Effects of travel motivation, past experience, perceived constraint, and attitude on revisit intention. Journal of Travel Research, 48(1), 29-44.

Hung, K., \&Petrick, J. F. (2012). Testing the effects of congruity, travel constraints, and self-efficacy on travel intentions: An alternative decision-making model. Tourism Management, 33(4), 855-867.

Kock, N. (2012). WarpPLS 3.0 user manual. Laredo, TX: ScriptWarp Systems.

Mechinda, P., Serirat, S., \&Gulid, N. (2009). An examination of tourists' attitudinal and behavioral loyalty: Comparison between 
domestic and international tourists. Journal of vacation marketing, 15(2), 129-148.

Prayag, G., Hosany, S., Muskat, B., \& Del Chiappa, G. (2017). Understanding the relationships between tourists' emotional experiences, perceived overall image, satisfaction, and intention to recommend. Journal of Travel Research, 56(1), 4154.

Ramkissoon, H., Uysal, M., \& Brown, K. (2011). Relationship between destination image and behavioral intentions of tourists to consume cultural attractions. Journal of Hospitality Marketing \& Management, 20(5), 575-595.

Stylos, N., Vassiliadis, C. A., Bellou, V., \&Andronikidis, A. (2016). Destination images, holistic images and personal normative beliefs: Predictors of intention to revisit a destination. Tourism Management, 53, 40-60.

Yoon, Y., \&Uysal, M. (2005). An examination of the effects of motivation and satisfaction on destination loyalty: a structural model. Tourism management, 26(1), 45-56.

Zhang, H., Fu, X., Cai, L. A., \& Lu, L. (2014). Destination image and tourist loyalty: A meta-analysis. Tourism management, 40, 213-223. 